\title{
Struktur Sosial Masyarakat Bima Pada Masa Kepemimpinan Sultan Muhammad Salahuddin Tahun 1915-1951
}

\author{
M Al Qautsar Pratama \\ Cecep Somantri \\ Jurusan Sejarah Kebudayaan Islam \\ Pascasarjana UIN Sunan Gunung Djati Bandung \\ qautsaral@gmail.com
}

\begin{abstract}
Bima's society has its own styles and social structures in the history's journey and it keeps changing. Social structure in Bima is not apart from the influence of their current goverment. In the goverment of Sultan Muhammad Salahuddin as the latest sultan in 1915 - 1951, he gave a lot of contributions to social and spiritual of Bima's society. This study concerns about the development of Bima's society that describes about the social status and also the symbols. This study also describes about the social life in every stat us and the policies of Sultan Muhammad Salahuddin that influence the social paradigm of Bima.
\end{abstract}

Keywords: Social structures, Bima's society, Sultan Muhammad Salahuddin

\section{Pendahuluan}

Bima merupakan sebuah daerah yang terletak di bagian Timur Pulau Sumbawa dan salah satu kabupaten dalam Provinsi Nusa Tenggara Barat. Secara geografis Bima adalah salah satu wilayah yang cukup strategis di wilayah kepulauan Nusa Tenggara. Wilayah bagian Utara berbatasan langsung dengan laut Flores, sebagai urat nadi perniagaan Nusantara sejak abad ke- $14 \mathrm{M}$. Terletak di tengah rangkaian kepulauan Nusantara dan memiliki pelabuhan alam yang terlindung dari serangan gelombang dan angin musim barat. Hasil alam Bima cukup beragam dan menjadi bahan ekspor yang sangat laris pada zamannya. Inilah yang menjadi alasan Bima 
bisa tampil sebagai Negara maritim tersohor sejak abad ke-15 sampai pertengahan abad ke- $20 \mathrm{M}$.

Daerah Bima atau yang biasa dikenal dengan istilah "Dana Mbojo" telah mengalami perjalanan panjang dan berliku. Fase perkembangan Bima dimulai sejak era pra-sejarah, Hindu-Budha, fase kerajaan kemudian berubah menjadi Kesultanan kemudian masuk ke fase NKRI dan sampai sekarang. Di masa pemerintahan Sultan Muhammad Salahuddin kehidupan sosial masyarakat Bima sangat beragam. Dalam tulisan ini penulis berusaha untuk mengungkap struktur masyarakat Bima yang menggabarkan adanya tingkat sosial masyarakat serta lambang-lambang statusnya. Terutama pada kepemimpinan Sultan Salahuddin sebagai Sultan terakhir di Bima. Sultan Muhammad Salahuddin sebagai sultan terakhir Kesultanan Bima memiliki peranan yang sangat penting dalam proses kemajuan Islam di tanah Bima. Sultan Salahuddin merupakan salah satu pemimpin yang memiliki integritas tinggi dalam menjalankan roda pemerintahan Kesultanan Bima.

\section{Sejarah Kesultanan Bima}

Kesultanan Bima merupakan salah satu wilayah yang memiliki peranan penting dalam panggung sejarah Islam khususnya di kawasan Nusa Tenggara. Jauh sebelum terjadinya proses pengislaman, Bima sudah menjadi daerah dengan perkembangan perdagangan yang cukup pesat. Menurut catatan Bo Sangaji $\mathrm{Kai}^{3}$, cikal bakal daerah Bima dirintis oleh pendatang dari Jawa yang bernama Sang Bima yang kemudian menikah dengan Putri Tasi Sari Naga. Dari pernikahan tersebut melahirkan dua orang putra yang bernama Indra Zamrud dan Indra Komala, kedua anaknya tersebutlah yang menjadi cikal bakal keturunan raja-raja Bima. ${ }^{4}$ Dalam catatan lainya disebutkan bahwa Ncuhi Dara dan Padolo menyampaikan keputusan pada saat Sang Bima memahat Wadu Pa'a mungkin dilakukan oleh Sang Bima yang beragama Hindu Siwaistik atau orang-orang Hindu yang hilir mudik melewati Flores kala itu.

Kuat dugaan dia sedang memimpin ekpedisi yang singgah di Pulau Satonda kemudian tiba di teluk Bima. Bisa dikatakan bahwa sang Bima

\footnotetext{
${ }^{1}$ Alan Malingi, Upacara Adat Hanta Ua Pua (Bima: Masehi Persada, 2010), Hlm. 12.

2 Dana Mbojo merupakan sebutan daerah Bima yang biasanya di sebutkan dalam kehidupan sehari-hari pada masyarakat Bima atau jika diterjamahkan dalam bahasa Indonesia berarti tanah Bima.

${ }^{3}$ Bo Sangaji Kai merupakan naskah kuno milik Kerajaan Bima, aslinya ditulis menggunakan aksara Bima. Naskah ini kemudian ditulis ulang pada abad ke-19 dengan menggunakan huruf ArabMelayu, menggunakan kertas dari Belanda dan Cina.

${ }^{4}$ Abdullah Tajib, Sejarah Dana Mbojo (Jakarta: Harapan Massa, 1999), Hlm. 11.
} 
merupakan orang yang memiliki andil penting dalam pendirian kerajaan Bima Hindu namun raja pertama yang memimpin kerajaan Bima yakni putranya Indra Zamrud yang diasuh oleh Ncuhi Dara. Menurut Morris kedatangan Sang Bima ke tanah Mbojo, berhasil mengubah pola kehidupan terutama pada bidang pertanian dan peternakan pada masyarakat Bima bahkan Sang Bima juga dilibatkan dalam pengambilan keputusan adat. Hal tersebut merupakan pertimbangan bagi masyarakat setempat untuk memberikan penghormatan sehingga Sang Bima diangkat sebagai pemimpin dan sebagai penghargaan lain maka nama Sang Bima disepakati sebagai nama Bima yang sebelumnya bernama Mbojo. ${ }^{5}$ Pada masa sebelum masuknya Islam Bima terbagi menjadi beberapa wilayah. Tiap wilayah dikuasai oleh kelompok masyarakat yang dikepalai oleh seorang "Ncuhi" 6

Zaman "Ncuhi" dipandang oleh orang Bima sebagai permulaan bagi rentetan kehidupan dan oleh karena itu zaman "Ncuhi". Disebut juga zaman "zaman ncuhi ro naka". Masa Ncuhi Merupakan ambang sejarah (Proto Sejarah) pada masa ini masyarakat mulai hidup berkelompok, menetap, mengenal pertanian dan peternakan dan masyarakat hidup teratur dibawah pimpinan seorang Ncuhi Menurut tuturan orang Bima yang dimaksud dengan "Ncuhi" adalah "edere domo dou, ina mpuu naba weki marimpa di siri wea nggawo na, di batu wea lele na". Pengertian "Ncuhi". Berdasarkan tuturan tersebut adalah Ncuhi adalah orang yang menjadi sumber kelahiran bagi turunan secara terus-menerus dan merupakan manusia pertama yang menjadi cikal bakal kelompok masyarakat yang bertanggung jawab untuk memberi perlindungan bagi seluruh masyarakat dan dijadikan sebagai sumber hokum yang wajid ditaati. ${ }^{7}$

Dalam naskah Bo dijumpai bahwa masyarakat pada masa itu sudah mengenal jenis tombak, parang, bercocok tanam, di daerah pengunungan dan berternak dan mereka belum mengenal sistem pengolahan tanah persawahan serta bajak-membajak. Kehidupan masyarakat zaman Ncuhi mengalami perubahan setelah datangnya imigran Jawa yang tidak ditemui sumber kuat kapan orang Jawa datang ke tanah Bima namun dalam buku Sejarah Nasional Indonesia yang diterbitkan oleh Kemendikbud orang Jawa datang

\footnotetext{
${ }^{5}$ Abdullah Tajib, Sejarah Dana Mbojo, Hlm 20

${ }^{6}$ Ncuhi dalam bahasa Indonesia bisa diartikan sebagai tokoh adat atau ketua adat yang memimpin beberapa wilayah tertentu di Bima dengan karakteristik masing-masing contohnya Ncuhi Doro Wani memimpin daerah bagian timur Bima, Ncuhi Dara memimpin wilayah Tengah kemudian Ncuhi Bolo yang memimpin daerah Bima bagian barat.

7 Abdul Gani Abdullah, Bima Dalam Lintasan Sejarah (Bima: Genta Publishing, 2015), Hlm. 67.
} 
ke tanah Bima sekitar tahun $1575 .{ }^{8}$ Perkiraan tersebut belum bisa dijadikan sebagai acuan dikarenakan ekspansi perluasan wilayah Majapahit ke arah Timur dilakukan antara lain menaklukan Bima pada tahun $1357 .{ }^{9}$ Data itu menunjukan bahwa sebelum tahun 1357 diperkiran telah datang imigran di Bima. Dalam naskah Bo hanya di jumpai bahwa kedatnagan Imigran jawa saat sebelum pergantian nama "Mbojo" menjadi Bima tanpa menyebutkan angka tahunnya.

Pada awal XVII Kerajaan Bima mengalami kemelut politik yang berkepanjangan, terjadi intrik politik yakni perebutan kekukasaan dengan serangkaian pembuhunhan dan intrik. Salisi yang merupakan putra raja $\mathrm{Ma}$ Wa'a Dampa merebut kekuasaan dengan melakukan cara licik bahkan berafiliasi dengan Belanda untuk mencapai kekuasaan di Bima bahkan Salisi membunuh terhadap putra mahkota kearjaan yakni Sangaji Samara yang berusia 9 tahun. Salisi menjadi raja Bima tanpa persetujuan majelis adat. Salisi yang merupakan raja Bima yang terakhir berhasil digulingkan oleh $\mathrm{La}$ $K a ' i$ yang didukung oleh seluruh rakyat dan bala tentara bantuan dari kerajaan Gowa selama tiga kali ekspedisi. Perjuagan La Ka'i adalah perjuangan panjang dan berdarah. ${ }^{10}$

Hubungan Bima dengan Gowa-Tallo di Sulawesi Selatan dalam periode kebebasan zaman bahari orang Makassar sekitar tahun 1567-1575 adalah salah satu tali penyambung yang memuluskan jalannya proses ismalmisasi di Bima. Hubungan Bima dengan kerajaan-kerajaan di Makassar dan Bugis dalam periode itu memberi kemungkinan terjalinnya hubungan dengan Bima jauh sebelum pertengahan abad ke XVI itu. Akan tetapi pengaruh yang dominan terhadap tahap-tahap pengislaman Bima adalah hubungan maritime yang terjadi sejak abad ke-XVI hingga permulaan abad ke-XVII. ${ }^{11}$

Menurut Sejarawan Bima M. Hilir Ismail, tahun 1540 M meruapakan tonggak awal kedatangan Islam di tanah Bima, proses islamisasi itu berlangsung dalam tiga tahap yaitu periode kedatangan Islam tahun 15401621, periode pertumbuhan Islam tahun 1621-1640 M, dan periode kerajayaan Islam 1640-1950 M. Pada awal sebelum Islam menjadi agama resmi kerajaan, ajaran Islam sudah masuk dan menyebar ke wilayah-wilayah

${ }^{8}$ Sejarah Nasional Indonesia Jilid III (Jakarta: Departemen Pendidikan Dan Kebudayaan RI 1977), Hlm. 270

9 Slamet Mulyana, Nagarakertagama dan Tafsir Sejarahnya (Jakarta: Bharatara Karya Aksara, 1977), Hlm. 120.

${ }^{10}$ M. Hilir Ismail, Raja dan Sultan Bima (Pemerintah Kabupaten Bima, 2014), Hlm. 5.

${ }^{11}$ Abdul Gani Abdullah, Bima Dalam Lintasan Sejarah (Bima:Genta Publishing, 2015), Hlm. 69. 
pesisir pantai Bima. ${ }^{12}$ Proses pengislaman di tanah Bima diklasifikasikan oleh Muhammad dapat terbagi dalam empat fase. Pertama, pada abad XIV masyarakat Bima telah mengetahui tentang adanya agama Islam yang dianut oleh masyarakat pulau Jawa. Kedua, pada abad itu juga, datangnya para utusan/mubalig melalui pintu perdagangan dari Jawa, khususnya dari kesultanan Demak dan Gresik, untuk menyebarkan Islam di Bima. Ketiga, adanya beberapa orang masyarakat Bima yang memeluk agama Islam. Keempat, masuknya masyarakat Bima ke dalam Islam secara massal. ${ }^{13}$

Pada tanggal 5 Juli $1640 \mathrm{M}$ menjadi tonggak berdirinya kesultanan Bima dengan Sultan pertama Abdul Khair (La Ka'i) dan perdana menteri La Mbila memeluk Islam dan berganti nama menjadi Jalaludin. Bima memasuki era kesultanan yang berlandaskan Islam dalam menjalankan pemerintahannya. Sebenarnya, masyarakat Bima sudah mengenal Islam melalui penyebar agama islam dari tanah Jawa, Melayu bahkan Gujarat dan Arab pada tahun $1609 \mathrm{M}$, yang mengenal lebih dulu adalah masyarakat pesisir. Masa kesultanan merupakan masa kejayaan Bima. Bima secara politik dan ekonomi berubah menjadi salah satu daerah perdangangan paling berpengaruh di wilayah Nusa Tenggara pada awal abad ke-16. Islam dimasa kesultanan bersinar cemerlang dan mencapai puncak kejayaan. Selama menjadi Kesultanan,

Bima di pimpin oleh 15 Sultan dalam kurun waktu 322 tahun mulai tahun 1640 M sampai tahun 1951 pasca wafatnya Sultan Muhammad Salahuddin. Menurut Morris (1890), selama berlangsungnya Kesultanan Bima, ada 49 raja dan rultan yang pernah memimpin di Bima. Maharaja Sang Bima diposisikan pada urutan ke-11, sedangkan dalam catatan Rouffaer yang kemudian diterbitkan oleh Noorduyn (1987), ada 26 raja atau sultan, mulai dari Maharaja Sang Bima sampai dengan Sultan Ibrahim. Sesungguhnya sejak muncul sebagai pusat kekuasaan Islam hingga tahun 1950, Kesultanan Bima diperintah oleh empat belas sultan, mulai dari Sultan Abdul Kahir (1620-1640) sampai Sultan Muhammad Salahuddin (19151951) sebagai Sultan Bima yang terakhir. Dalam proses estafet kepemimpinan di Kesultanan Bima, tiap sultan memiliki strategi tersendiri dalam menjalankan roda pemerintahanya. Sultan disamping memiliki kedudukan yakni sebagai kekuasaan tertinggi dalam Kerajaan Bima, ia juga

\footnotetext{
${ }^{12}$ Abdul Gani Abdullah, Bima Dalam Lintasan Sejarah, Hlm. 11

${ }^{13}$ Muhammad Ahmad, "Hubungan Goa dan Aceh dalam Proses Islamisasi Kerajaan Bugis Makassar”, dalam Andi Rasdianah (ed.), Bugis Makassar dalam Peta Islamisasi Indonesia, IAIN Ujung Pandang, 1982.
} 
berkedudukan sebagai pemimpin tertinggi majelis $S u b a^{14}$ dalam Kesultanan Bima.

Era kesultanan bertepatan dengan masa penjajahan di Nusantara. Hinga tidak heran berbagai kepetingan penjajah terutama bangsa Belanda juga merambah di Bima. ${ }^{15}$ Sultan-sultan yang memimpin sebelum sultan Muhammad Salahuddin lebih menfokuskan pada pada persoalan masyarakat seperti memperbaiki kehidupan rakyat dalam bidang pertanian akibat kemarau, serangan bajak laut, kemiskinan, kelaparan dan juga tidak terlepas dari perang melawan kolonial Belanda. Sedangkan di era sultan Salahuddin Bima lebih diperhatikan dalam berbagai aspek kehidupan yang sangat terlihat adalah aspek agama dan pendidikan.

Sultan Muhammad Salahuddin sebagai sultan terakhir Kesultanan Bima memiliki peranan yang sangat penting dalam proses kemajuan Islam di tanah Bima. Sultan Salahuddin merupakan salah satu pemimpin yang memiliki integritas tinggi dalam menjalankan roda pemerintahan Kesultanan Bima. Ia lahir di Bima pada tanggal 15 Zulhijah 1306 Hijriah atau 14 Juli 1889 dan meninggal dunia pada tanggal 11 Juli 1951 merupakan putra mahkota dari Sultan Ibrahim. ${ }^{17}$ Sejak usia muda ia sudah tertarik dengan hal-hal yang berkaitan dengan ilmu keagamaan, pendidikan, dan politik. Sultan Muhammad Salahuddin banyak belajar tentang ilmu pemerintahan dan agama dari ulama dan pejabat istana pada saat itu. Ia juga menekuni ilmu tauhid, serta siasat politik, ia selalu membaca buku-buku, dan rajin mempelajari ilmu Qur'an dan Hadist. Selian mendapat bimbingan dari pala ulama setempat beliau juga berguru pada ulama yang didatangkan dari Batavia yaitu H. Hasan dan Syeh Abdul Wahab dari Mekakah. ${ }^{18}$

Berdasarkan faktor-faktor diatas pada tanggal 2 November 1899 beliau resmi diangkat sebagai "Jena Teke" 19 oleh majelis Hadat. Kemudian untuk mendapatkan pengalaman lebih jauh dalam menjalankan roda

${ }^{14}$ Majelis ini mencakup Sultan anggota majelis "Hadat" "Syara Tua”. Istilah Suba ini selain bermakna rakyat juga bermakna angkatan militer. Makna-makna tersebut memiliki kaitan juga dengan istilah "Sera Suba" yang berarti alun-alun atau lapangan luas. Masyarakat Bima kadang-kadang menyebutnya dengan Seraba.

15 Tawaluddin Haris, Kerajaan Tradisional di Indonesia: Bima, (Jakarta: Gramedia, 2004), Hlm. 294. 49.

${ }^{17}$ M. Hilir Ismail, Raja dan Sultan Bima, (Bima: Pemerintah Kabupaten Bima, 2014), Hlm.

${ }^{18}$ M. H Hilir Ismail, Raja dan Sultan Bima, Hlm. 50.

19 Jena Teke berarti Putera Mahkota, Sultan Salahuddin meruapakan satu-satunya anak dari Sultan Ibrahim yang diangkat sebagai putera mahkota dari 11 bersaudara. 
pemerintahan, maka pada tanggal 23 Maret 1908 diangkat menjadi Jeneli Donggo atau setingkat camat dalam hirarki kepemimpinan Kesultanan Bima. Setelah sang ayah Sultan Ibrahim mangkat pada tahun 1915, Muhammad Salahuddin mengambil alih kekuasaan pemerintahan kemudian tahun 1917 resmi dilantik menjadi sultan Bima ke-XVI yang memerintah dari tahun 1915-1951 M. Disamping menjadi sultan, pada tahun 1949 diangkat menjadi Dewan Raja-raja se-Pulau Sumbawa atas persetujuan Sultan Dompu dan Sultan Sumbawa. Sultan Salahuddin sangat fokus pada pembangunan dalam bidang sosial keagamaan dan pendidikan Islam. Pada proses menjalankan tampuk kekuasaan Sultan Muhammad Salahuddin banyak mendapatkan rintangan dan tantangan.

Pada masa kekuasaanya Bima sedang mengalami krisis politik dan ekonomi yang cukup memprihantinkan akibat ulah dari penjajah. Namun tantangan tersebut dilalui dengan jiwa besar dan keyakinan yang teguh. Beliau melalui tantangan tersebut melalui proses yang panjang. Penulis tertarik meneliti tentang Sultan Salahuddin dikarenakan selain sosok yang sangat dihormati dan dicintai oleh masyarakat Bima. beliau juga merupakan satu-sat unya sultan yang memiliki ketertarikan yang tinggi terhadap paham keagamaan, pendidikan, ekonomi dan politik bahkan Sultan Salahuddin dijuluki sebagai "Ma ka kidi Agama" atau tokoh yang mendirikan, memajukan dan menjalankan ajaran agama Islam ditanah Bima. Sultan Salahuddin merupakan tokoh utama yang berperan penting dalam perkembangan sejarah Bima pada awal abad ke 20.

\section{Penggolongan Sosial Masyarakat Bima}

Pada masa pemerintahan sultan Muhammad Salahuddin, pengolongan masyarakat Bima masih sama seperti pada masa sebelumnya dalam artian belum ada perbedaan yang terlalu mencolok. Pada masa itu masyarakat Bima digolongkan menjadi 4 golongan yaitu (1) golongan rajaraja, (2) golongan bangsawan, (3) golongan dari dan pegawai istana, (4) golongan rakyat biasa. Pihak kesultanan secara resmi hanya mengakui keempat status tersebut. Penggolongan tersebut tidak memberikan kesan bahwa masyarakat Bima terbagi dalam suku bangsa akibat pertalian wilayah. Demikian pula istana tidak mengakui adanya golongan budak walaupun goglongan tersebut hidup berdampingan dengan raja-raja dan bangsawan. Status golongan budak yang demikian mungkin karena golongan ini merupakan penduduk pendatang atau bukan asli orang Bima atau bahkan dari hasil barter dengan pihak lain. 
Penggolongan masyarakat Bima diinterpretasikan dalam bentuk lambang pemerintahan yang bermakn: (1) terjemahan dari suatu tuntutan bahwa dalam fungsi pemerintahan hanya dipegang oleh raja, bangsawan, dan pegawai istana, ${ }^{20}(2)$ merupakan suatu pengawasan yang ketat terhadap distribusi tugas dan fungsi dalam pemerintahan kesultanan dan (3) upaya untuk menutup kemungkinan bagi golongan rakyat biasa memperoleh tugas dan fungsi yang sama dalam pemerintahan.

Penggolongan masyarakat Bima ini juga memiliki kaitan erat dengan pelayanan yang diinginkan oleh keluarga istana. Golongan lainnya merasa bahwa mengakomodasikan keterampilan terhadap golongan raja dan bangsawan berarti akan meraih kebutuhan individualnya. Oleh karena itu, analisis tiap golongan masyarakat dapat ditekanakan pada angota golongan, batasan distribusi golongan, aktivitas pokoknya dan pantangan bagi anggota kelompok yang bersangkutan.

1. Golongan raja-raja merupakan golongan yang memilki kedudukan tertinggi di Kesultanan Bima. Golongan ini menuntut secara turun-temurun sebagai golongan yang merupakan keturunan asli Sang Bima. Sehingga memilki kedudukan sebagai sultan di Bima pada saat itu. Anggota atau orang yang termasuk di dalam golongan ini ialah raja yang pernah memimpin atau sedang memimpin beserta istri dan anak-anaknya. ${ }^{21}$ Mereka inilah yang dinamakan orang Bima "londo sangaji" atau keturunan raja. Seorang raja atau anak raja tidak menutup kemungkinan untuk menikahi seorang wanita dari golongan rakyat biasa. Apabila terjadi hal demikian maka golongan wanita yang dinikahi akan berubah menjadi sama seperti sultan. Golongan raja-raja bertempat tinggal di dalam lingkungan kesultanan. Raja dan istrinya harus tinggal di istana pusat sedangkan keluarga lain akan tinggal di luar istana.

Pada masa kepemimpinan Sultan Salahuddin raja menepati dan melaksanakan tugasnya di 'asi nae' istana besar sedangkan keluarga lain tinggal di 'asi mpasa' atau bekas istana atau istana lama. Jika ditelisik dari sanksi hukum kelurga raja memiliki keistimewaan dibanding golongan lain.

${ }^{20}$ Bandingkan dengan Jean Peaget, Structuralisme. Transleted and adited by Chaninah Maschler, Basic Books. Inc. Publisher. New York, Hlm. 115

${ }^{21}$ Abdul Gani, Peradilan Agama dalam Pemerintahan Islam di Kesultanan Bima 1947-1957, (Yogjakarta: Genta Publishing, 2004) hlm. 90 
Hukuman golongan raja ketika melakukan pelanggaran sangat ringan. Hal ini tercantum dalam pasal 5 ketentuan tanggal 15 Dzulhijjah 1284 seperti yang tercantum dalam naskah bo disebutkan bahwa jikalau anak raja membuat malu atau memukul seorang hamba atau rakyat biasa maka akan dijatuhi denda sebesar 8 real. Dalam pasal 6 disebutkan bahwa jikalau anak raja memaki orang atau rakyat biasa akan dikenakan denda sebesar 4 real. Sebaliknya dipasal 7 jikalau seorang rakyat biasa melakukan hal yang sama akan didenda sebanyak 12 real. Ketentuan hukum ini mencerminkan adanya perbedaan tingkat sosial yang mencolok antara raja dengan rakyat biasa.

2. Golongan bangsawan: golongan masyarakat Bima yang ada dibawah tingkatan raja ialah golongan bangsawan. Keturunan bangsawan menjabat jabatan tertentu dalam pemerintahan secara turun-temurun sehingga keturunan selanjutnya dimungkinkan untuk memilki anggapan bahwa memangku jabatan itu merupakan pengakuan hukum bagi kelanjutan kebangsawanannya.

Dikalangan masyarakat Bima sebenarnya belum terdapat kejelasan mengenai siapa yang memiliki hak untuk dikatakan sebagai keturunan bangsawan atau termasuk 'londo ruma' atau 'londo sangaji atau keturunan raja. Namun jika dilihat dari fungsingnya dalam pemerintahan, sebagian besar masyarakat Bima berpendapat bahwa orang yang termasuk golongan bangsawan yakni mereka yang menduduki jabatan Tureli, Jeneli, dan Bumi dalam lingkunagn Bumi Nae.

Golongan bangsawan pada awalnya bermukim dilingkungan istana. Sebagaian besar golongan ini tinggal didaerah tertentu yang disebut "kampo nae" (kampung besar), kampung ini merupakan lokasi khusus pemukiman pembesar pemerintah. Hampir keseluruhan mereka adalah bangsawan di kota karena jarang sekali golongan bangswasan yang tinggal di pedesaan atau wilayah yang jauh dari pusat kerajaan.

Pada masa peralihan pemerintahan sekitar tahun 1957, golongan bangsawan mengalami kekhawatiran. Disatu sisi mereka takut akan kehilangan charisma sebagai seorang bangsawan akibat sempitnya memperoleh jabatan-jabatan dalam lembaga pemerintahan. Dan disisi lain mereka sendiri 
tidak berhasil menformulasikan tingkat sosial yang ingin dipertahankan itu sehingga tidak ada patokan untuk membedakan golongan bangsawan dengan masyarakat biasa.

3. Golongan Pegawai Istana. Golongan ini pada awalnya merupakan kelompok masyarakat dari golongan rakyat biasa yang diangkat bekerja sesuai dengan perintah istana sesuai dengan keahliannya yang dibutuhkan dalam lingkungan istana. Mereka dinggap sebagai kelompok masyarakat tersendiri karena golongan ini terdiri dari pegawai rendahan, pesuruh atau tukang yang disuruh untuk melaksanakan pekerjaan tertentu di luar maupun di dalam lingkungan istana.

Menurut Ahmad Amin pembagian kelompok berdasarkan dari tugas, fungsi, dan tanggung jawabnya dalam istana. Karena itu cenderung diakui bahwa seluruh pegawai istana dibawah koordinasi Bumi Parenta dan Bumi Renda. Tugas dan tanggung jawab mereka dalam koordinasi Bumi Parenta meliputi pengawasan di dalam dan luar istana, pekerjaan sebagai pesuruh, urusan kesenian istana dan perlengkapannya, urusan produksi perlengkapan istana, urusan tenaga kerja dalam istana. Sebagaian dari mereka bertempat tinggal tetap di pedesaan dan sebagaian lainnya bertempat tinggal di sekitar istana. Pemilihan tempat tinggal tersebut didasarkan pada alasan tuntutan kewajiban bertugas dan banyak tidaknya pekerjaan di dalam istana. ${ }^{22}$

4. Golongan rakyat biasa adalah masyarakat yang tidak termasuk dalam golongan raja-raja, bangsawan ataupun pegawai istana. Golongan ini lebih dianggap sebagai golongan dengan kelas sosial paling rendah dalam masyarakat Bima. Golongan ini biasanya melakukan aktivitas sehari-hari sebagai petani, pedagang, bahkan sebagai pesuruh kaum raja atau bangsawan, ada juga yang berburu, dan sebagian nelayan. Golongan rakyat biasa pada kehidupan sehari-hari juga menduduki fungsi keagamaan seperti fungsi sebagai guru ngaji, atau murid. Fungsi-fungsi keagamaan itu melahirkan tingkat sosial diantara mereka.

Kalangan rakyat biasa tidak bisa mengikuti pola hidup kaum raja-raja atau bangsawan. Rakyat biasa bisa dikatakan

${ }^{22}$ M. Nur Wahab, Sejarah Bima Sekilas Lintas, dalam brosur Kenang-kenangan Tiga Tahun IKIPBima (Raba: IKIP Mataram, 1973) hlm. 153 
tergolong bebas dalam bertindak tidak seperti golongan raja dan bangsawan yang terlihat lebih kaku dan mengikuti pakem istana. Dalam kehidupan masyarakat biasa lebih cenderung dikungklung oleh adat istidat dan perintah agama. Jika ada beberapa individu atau kelompok masyarakat biasa yang keluar dari jalur perintah agama maka akan ditegur dengan munculnya slogan "na kanta ku ba ruma" (dilarang oleh tuhan) atau "wati pehe, wati tahona" (tidak baik). Pantanganpantangan hidup bagi golongan rakyat biasa yang erat sekali kaitannya dengan tradisi istana dan dekat dengan ajaran agamanya.

\section{Lambang Status Sosial Masyarakat Bima}

Pembagian masyarakat Bima seperti yang dijelaskan diatas merembet pula pada hak pemakaian gelar yang melambangkan status golongan masyarakat. Pada masa pemerintahan Sultan Muhammad Salahuddin pemakaian gelar dalam kehidupan masyarakat Bima masih digunakan bahkan masih memiliki pengaruh yang sangat besar dalam kehidupan sehari-hari. Namun, sejak akhir tahun $1967^{23}$ gelar tidak lagi melambangkan perbedaan status sosial dalam masyarakat Bima. Dalam hal gelar masyarakat Bima cenderung memperolehnya melalui 4 jalur yakni:

1. Gelar yang diperoleh akibat garis keturunan

Golongan raja-raja menyandang gelar "ruma" 24 karena mereka adalah "londo sangaji”" (keturunan raja). Gelar ruma selalu diikuti oleh nama atau panggilan diri, seperti "ruma sangaji" bagi seorang raja atau sultan. Dalam golongan rajaraja istilah sultan saja dipandang sebagai gelar dalam jabatan raja, pertanda kerajaan Islam. Apabila ia tidak menjadi lagi maka gelar sultan tidak di pakai lagi keculai gelar ruma. Ruma mone adalah gelar bagi anak laki-laki raja sedangkan bagi perempuan diberikan gelar ruma siwe.

\footnotetext{
23 Pelaksanaan pembangunan yang dimulai sejak tahun 1969 membawa perubahan bagi tingkat kesadaran orang Bima untuk terpacu meningkatkan taraf hidupnya: gelar tidak menjadi penghalang untuk mencapai tingkat kehidupan ekonomi yang baik sebagaimana golongan raja-raja dan bangsawan.

${ }^{24}$ Istilah "ruma" dalam bahasa Bima bermakna Tuhan. Dalam kaitannya dengan tulisan ini "ruma" dipakai orang Bima sebagai lambang status golongan raja-raja, karena golongan ini, terutama sang raja adalah orang yang berkedudukan tinggi di Bima. Dengan kedudukan itu, ia berhak memakai istilah "ruma" sebagai gelarnya.
} 
Masih ada gelar yang mengungkapkan golongan rajaraja itu dekat dengan golongan biasa, seperti gelar "ina ka' u" (ibu yang mulia), dan "ama ka'u”' (bapak yang mulia) ina atau ama biasanya dipakai untuk panggilan seorang ayah dan ibu pada golongan rakyat biasa.

2. Gelar yang diperoleh setelah memangku jabatan tertentu.

Gelar yang dapat diperoleh melalui proses pemangkuan suatu jabatan di dalam lingkungan pemerintahan Kabupaten Bima dan terjadi di dalam golongan bangsawan atau golongan dari pegawai istana. Gelar-gelar itu diberikan oleh Pemerintahan Kesultanan secara resmi. Pada pemerintahan Sultan Muhammad Salahuddin golongan bangsawan yang memangku jabatan tingkat Turelli, Jeneli dan para pemangku jabatan Bumi Nae diberi gelar atau mendapat gelar "rato" gelar tersebut biasanya disebutkan sebelum nama jabatannya. ${ }^{25}$

Jabatan dalam Badan Hukum Syara' sejalan dengan jabatan Tureli Nggampo. Hingga Bumi Nae, jabatan Imam, lebenae dan cepelebe dalam Badan Hukum Syara' dan dipandang sejajar dengan jabatan Tureli Nggampo hinga Bumi Nae, Imam dan yang lainnya tidak dipandang sebagai golongan bangsawan walaupun memberikan kesempatan yang terbuka dan mempunyai peluang untuk masuk dalam kelompok masyarakat bergelar "rato".

3. Gelar-gelar yang terdapat dalam lingkungan rakyat biasa.

Kehidupan ekonomi masyarakat biasa tidak menempatkan mereka pada tingkat sosial yang berbeda. Kehidupan keagamaan justru memberi pengaruh bagi hubungan timbal-balik diantara mereka sehingga menyebabkan timbulnya tingkat sosial yang berbeda. Seorang anggota masyarakat dalam golongan rakyat biasa akan memperoleh kedudukan yang lebih tinggi dibandingkan yang lainnya apabila telah berhasil mencapai tingkat "tuan guru imam", "tuan guru", "guru imam", "guru lebe", atau "guru haji".

${ }^{25}$ Abdullah Tajib, Sejarah Dana Mbojo, Hlm 20 
Gelar-gelar tersebut dapat berupa anugrah sebagai pemangku jabatan dalam Badan Hukum Syara maupun pemberian masyarakat. Selain gelar-gelar yang disebutkan di atas, masih ada gelar-gelar lain, seperti "ruma guru", "haji", "ruma haji". Gelar tersebut bukan didapat melalui keturunan namun juga sama dengan gelar yang diberikan oleh masyarakat terhadap orang tersebut.

Ruma guru adalah gelar seorang guru yang mengajar agama Islam dalam lingkugan istana. Biasanya gelar itu disandang oleh orang Bima keturunan Melayu. Namun yang lebih dikenal oleh masyarakat bukanlah dari golongan Melayu melainkan dari orang Bima asli seperti ruma guru Haji Muhammad Said, Adbul Gani. Setelah itu barulah dikenal ruma guru Haji Ince Ma dan lain-lain.

Kemudian ada gelar "ruma haji" adalah gelar yang diperoleh seorang setelah menunaikan ibadah haji sebelum tahun 1951 yakni sebelum meninggalnya Sultan Muhammad Salahuddin sebagai Sultan Bima yang terakhir. Pada waktu pemerintahan Sultan Salahuddin terdapat suatu ketentuan tidak tertulis bahwa tiap orang Bima yang berangkat ke Mekkah baik untuk menunaikan ibadah haji atau untuk bermukim, diharuskan bersalaman dengan "ruma sangaji" dan demikian pula setelah kembali dari Mekkah sebelum ke desa masing-masing.

Acara bersalaman tersebut dimanfaatkan oleh Sultan untuk memperoleh berita atau keterangan kemungkinan ada ilmu baru atau kitab-kitab yang dibawa oleh para haji dari Mekkah. Apabila ketentuan tersebut tidak dipatuhi maka yang bersangkutan akan dikenakan hukuman berupa kewajiban duduk di "lare-lare" (pintu gerbang utama istana Bima) selana tiga hari beruntun. Sejak meninggalnya Sultan Salahuddin ketentuan itu tidak berlaku lagi dengan sendirinya karena menurut anggapan masyarakat Bima, sudah tidak ada lagu=I gelar tersebut karena orang-orang yang pergi haji setelah tahun 1951 diberikan gelar "abu" (bapak) dan "umi" (ibu).

4. Variasi warna jubbah

Bagi golongan rakyat biasa, jubbah bukan merupakan suatu hal yang kaitannya dengan gelar. Jubah itu secara 
popular dipakai oleh orang yang sudah melaksanakan ibadah haji. akan tetapi di kalangan masyarakat tertentu masih ada yang menggunakan variasi warna jubbah seperti merah tua, hijau, dan putih dengan maksud tertentu. Jubah hijau biasanya dipakai oleh para haji yang berada di bawah tingkat jubbah merah tua. Mereka ini pada umumnya akan menggantikan pemakai jubah merah dalam berbagai perannanya. Jubah putih biasanya dipakai oleh sesoerang yang baru saja kembali dari ibadah haji yang akan menggatikan peranan jubah hijau nantinya.

\section{DAFTAR PUSTAKA}

Cholisin dan Nasiwan. Dasar-Dasar Ilmu Politik. Yogyakarta: Ombak, 2012.

Gani, Abdul. Peradilan Agama dalam Pemerintahan Islam di Kesultanan Bima 1947-1957. Yogyakarta: Genta Publishing, 2004.

Haris, Tawaluddin. Kerajaan Tradisional di Indonesia: Bima. Jakarta: Gramedia, 2004.

Ismail, M. Hilir. Raja dan Sultan Bima. Pemerintah Kabupaten Bima, 2014.

Malingi, Alan. Upacara Adat Hanta Ua Pua. Bima: Masehi Persada, 2010.

Morris, D.F. Van Braam. Kerajaan Bima 1886. Bima: Lengge Pres, 2001.

Muhammah, Ahmad. Hubungan Goa dan Aceh dalam Proses Islamisasi

Kerajaan Bugis Makassar, dalam Andi Rasdianah (ed.), Bugis

Makassar dalam Peta Islamisasi Indonesia, IAIN Ujung Pandang, 1982.

Mulyadi, Sri. Bandar Bima. Jakarta: Departemen Pendidikan dan Kebudayaan, 1993.

Mulyana, Slamet. Nagarakertagama dan Tafsir Sejarahnya. Jakarta: Bharatara Karya Aksara, 1977.

Tajib, Abdullah. Sejarah Dana Mbojo. Jakarta: Harapan Massa, 1999. 